\title{
PENERAPAN TEORI KENYAMANAN KOLCABA PADA ANAK YANG MENGALAMI PENINGKATAN SUHU TUBUH
}

\section{CASE STUDY: THE APPLICATION OF THE COLCABA THEORY ON MEASUREMENT OF TEMPORAL ARTERIAL TERMOMETERS}

\author{
Immawati $^{1}$, Nani Nurhaeni ${ }^{2}$, Dessie Wanda ${ }^{2}$ \\ ${ }^{1}$ Akper Dharma Wacana Metro \\ ${ }^{2}$ Fakultas Ilmu Keperawatan, Universitas Indonesia \\ e-mail : $\underline{\text { inimmawati@gmail.com }}$
}

\begin{abstract}
ABSTRAK
Anak sangat berisiko tertular penyakit terutama penyakit infeksi karena sistem imunitas anak masih belum terbentuk sempurna. Salah satu tanda anak mengalami infeksi adalah demam. Demam merupakan salah satu gangguan kenyamanan fisik. Upaya memberikan kenyamanan anak yang mengalami demam dengan pendekatan teori kenyamanan Kolcaba adalah dengan pengukuran suhu menggunakan termometer arteri temporal. Metode: Pada penelitian ini menggunakan metode studi kasus yang bertujuan untuk mengetahui efektifitas pengukuran suhu arteri temporal pada anak yang demam. Studi kasus dilakukan pada kelima anak yang mengalami masalah peningkatan suhu tubuh. Hasil : Pengukuran suhu dengan termometer arteri temporallebih dirasakan nyaman oleh anak yang mengalami demam. Pembahasan: Pengukuran suhu temporal ini dirasakan lebih nyaman dan tidak menakutkan bagi anakkarena waktu pengukuran yang lebih singkat (kurang dari 2 detik). Kesimpulan: Perawat dapat melakukan pengukuran thermometer arteri temporal pada anak demam sebagai penerapan teori kenyaman Kolcaba dan pemberian intervensi keperawatan atraumatik.
\end{abstract}

Kata kunci: termometer temporal, teori kenyamanan Kolcaba.

\begin{abstract}
Background: Children who are most at risk of infected diseasescaused by the child's immune system are still not fully formed. One signs of a child having an infection is a fever. Fever is a physical comfort disorder. Efforts to provide comfort to children who improve fever by using the Kolcaba comfort theory is to use temperature measurements using a temporal arterial thermometer. Method: This research used case studydesign discusses how to measure temporal temperatures in children with fever. Case studies are conducted on children who fix body temperature problems. Assessment results obtained from children who have a fever caused by the infection process. Results of the intervention show that temperature measurement with a temporal arterial thermometer is more convenient for children who recover from fever. Temporal artery thermometers were obtained from four children who corrected the fever problem. This temporal temperature measurement feels more comfortable and not frightening for children because the measurement time is shorter (less than 2 seconds). Conclusion: Measurement of temporal artery thermometer in children with fever as the application of Kolcaba's comfort theory and the provision of atraumatic nursing interventions.
\end{abstract}

Keywords: temporal thermometer, Kolcaba comfort theory . 


\section{PENDAHULUAN}

Masa anak-anak merupakan masa dimana anak sangat mudah tertular penyakit. Pada masa ini penyakit yang terjadi pada anak terjadi karena sistem imunitas anak masih belum terbentuk sempurna. Infeksi saluran pernafasan dan saluran pencernaan merupakan penyakit yang sering ditemukan padaanak. Penyakit infeksi dapat bersifat sistemik ataupun fokal. Tandatanda infeksi yang bersifat sistemik antara lain demam. Demam yang terjadi pada anak yang mengalami infeksi merupakan reaksi tubuh terhadap infeksi bakteri yang serius, ataupun infeksi virus ringan ${ }^{1,2}$. Demam adalah suhu tubuh $38^{\circ} \mathrm{C}$ atau lebih. Demam terjadi karena ketidakmampuan mekanisme kehilangan panas dalam mengimbangi produksi panas yang berlebihan $^{3,4}$. Demam yang terjadi pada anak akan mempercepat reaksi-reaksi kimia $\mathrm{sel}^{3,4}$. Anak yang mengalami peningkatan suhu tubuh akan merasakan ketidaknyamananakibat demam yang dirasakan. Pengkajian demam yang akurat dapat dilakukan salah satunya melalui pengukuran suhu tubuh dengan termometer yang dapat menggambarkan peningkatan suhu tubuh inti. Pengukuran suhu merupakan aspek yang penting pada perawatan pasien. Untuk itu diperlukan alat pengukuran suhu yang digunakan yang tidak menimbulkan trauma.

Peran perawat untuk meminimalkan trauma dalam memonitor suhu tubuh sangat penting sebagai tenaga yang lebih banyak waktu berada bersama pasien ${ }^{3}$. Intervensi yang dilakukan perawat dalam pelaksanaan asuhan keperawatan harus dapat meningkatkan kenyamanan pasien. Salah satu intervensi adalah melakukan monitor suhu tubuh anak yang mengalami demam. Monitor suhu tubuh dilakukan menggunakan alat pengukur suhu menggunakan alat yang memberi kenyamanan anak yaitu menggunakan termometer arteri temporal ${ }^{5,6}$.

Beberapa model keperawatan menyatakan bahwa kenyamanan adalah kebutuhan dasar klien yang merupakan tujuan pemberian asuhan keperawatan. Pernyataan kenyamanan tersebut sesuai dengan konsep model kenyamanan menurut Kolcaba yang menyatakan bahwa kenyamanan adalah suatu keadaan telah terpenuhinya kebutuhan dasar manusia ${ }^{7}$.

Intervensi kenyamanan yang diberikan berdasarkan aplikasi model kenyamanan Kolcabaterbukti efektif memberikan kenyamanan pada pasien. Hal ini telah dibuktikan oleh Walsh dkk dalam penelitiannya yang menyatakan bahwa model kenyamanan Kolcaba sangat relevan diterapkan pada klien dengan gangguan kardiovaskuler dengan menerapkan intervensi "quite time".

Demam yang dialami pada anak dengan penyakit infeksi pada pengkajian taksonomi kenyamanan Kolcaba merupakan gangguan pada aspek kenyamanan fisik. Ketidaknyamanan fisik akibat demam yang dialami anak dapat diatasi dengan intervensi tehnikal berupa pemantauan suhu menggunakan alat pengukur suhu yang dirasakan nyaman oleh anak ${ }^{11}$.

Anak yang mengalami demam akan mengalami distres fisik yang dapat meningkatkan perasaan ketakutan dan kecemasan. Pemberian asuhan atraumatik dapat diberikan pada anak yang mengalami demam untuk mencegah dan meminimalkan stres tersebut. Asuhan atraumatik dapat diberikan melalui intervensi kenyamanan : 
teknik mengukur kenyamanan (technical comfortmeasures). Yaitu suatu intervensi yang didesain untuk mempertahankan homeostasis dan manajemen demam, seperti monitor tandatanda vital terutama suhu ${ }^{11}$. Intervensi kenyamanan yang penulis lakukan adalah pengukuran suhu menggunaan termometer yang membuat anak nyaman yaitu thermometer arteri temporal ${ }^{9}$.Ketepatan intervensi dalam meningkatkan kenyamanan anak yang mengalami demam sangat dibutuhkan. Alat Tujuan penelitian ini mendeskripsikan asuhan keperawatan pada anak yang mengalami demam melalui penerapan intervensi tehnikal pengukuran suhu arteri temporal dengan pendekatan teori kenyamanan Kolcaba.

Metode yang digunakan adalah studi kasus yang dilakukan di dua rumah sakit yaitu RSUPN Cipto Mangunkusumo dan RSAB Harapan Kita Jakarta yang dilakukan dari tanggal 15 Februari 2016 sampai 29 April 2016. Studi kasus dilakukan dengan memberikan asuhan keperawatan terhadap lima pasien kelolaan dengan penyakit infeksi akut yang mempunyai masalah keperawatan peningkatan suhu tubuh dengan menggunakan pendekatan teori kenyamanan Kolcaba. Kolcaba menilai kenyamanan dengan membuat struktur yang dimulai dari relief, ease dan transcendence. Kolcaba dalam teori kenyamanan ingin meningkatkan rasa nyaman klien yang berhubungan dengan pengalaman pasien yaitu pengalaman fisik, psikospiritual, sosiokultural dan lingkungan. Intervensi kenyamanan untuk pasien dilakukan melalui technical comfort pengukuran suhu sebaiknya menggunakan alat yang akurat dan tidak menimbulkan

trauma/ketidaknyamanan Berdasarkan uraian diatas penulis tertarik menerapkan teori kenyaman Kolcaba untuk mengatasi masalah demam pada anak yang mengalami peningkatan suhu tubuh menggunakan alat pengukuran suhu tubuh termometer arteri temporal agar mencapai kenyamanan anak measures, coaching, dan "comfort food for the soul" 10 .

\section{DESKRIPSI KASUS}

Asuhan keperawatan yang diberikan terhadap lima anak yang mengalami masalah peningkatan suhu tubuh di ruang infeksi menggunakan pendekatan teori kenyamanan Kolcaba. Kelima asuhan keperawatan diberikan terhadap By. M.R.A (laki-laki, 11 Bulan) dengan HIV Stadium IV Imunisupresi berat, Anak A.R.A.G (laki-laki, 1 tahun 11 bulan) dengan diare, anak M.R.S (laki-laki, 6,8 tahun) dengan TB Paru, epilepsi, Anak MH (laki-laki, 7,6 tahun) dengan HIV dan anak M.R.A.F (laki-laki, 8 bulan) dengan diare akut.

Pengkajian kenyamanan fisik kelima pasien kelolaan didapatkan anak mengalami peningkatan suhu tubuh (antara suhu $37,2^{\circ} \mathrm{C}-$ $38,6^{\circ} \mathrm{C}$ ), bab cair, batuk pilek dan kejang. Pengkajian aspek psikospiritual dapat dilakukan pada anak yang berusia diatas 3 tahun sedangkan pengkajian kenyamanan sosiokultural didapatkan kelima orang tua mengalami masalah kenyamanan sosiokultural terkait penyakit dan perawatan anaknya. Sedangkan hasil pengkajian lingkungan tidak ditemukan masalah kenyamanan. 


\section{Wacana Kesehatan Vol. 4 , No.2, Desember 2019}

Diagnosa keperawatan dari kelima pasien untuk masalah kenyamanan fisik adalah: bersihan jalan nafas tidak efektif, peningkatan suhu tubuh, kekurangan volume cairan, nutrisi kurang dari kebutuhan, gangguan keterlambatan pertumbuhan dan perkembangan anak, risiko kejang berulang, risiko komplikasi, gangguan pola eliminasi (bab cair) dan ansietas.

Pengalaman psikospiritual pada kelima kasus kelolaan hanya dua anak yang dapat mengungkapkan secara verbal yaitu pada anak $\mathrm{G}$ dan R.S yang dapat mengungkapkan rasa tidak nyaman. Sedangkan untuk ketiga anak yang lain dapat diketahui dari orang tua dimana orang tua menyatakan kekawatiran terhadap kondisi kesehatan anak.

Diagnosa keperawatan yang ditemukan ketidaknyamanan pada aspek sosiokultural adalah ansietas. Data yang ditemukan untuk mendukung masalah ini antara lain orang tua menyatakan kekawatiran terhadap kondisi kesehatan anak, klien merupakan anak ketiga dari tiga bersaudara. Anak selalu ditunggu ibu dan neneknya secara bersama. Anak sering dijenguk oleh kakeknya dan sesekali oleh ayahnya karena kedua orang tua klien telah bercerai. Masalah keperawatan ini dialami oleh kelima orang tua pasien kelolaan.

Intervensi keperawatan yang diberikan berfokus pada upaya peningkatan rasa nyaman anak dan keluarga, dengan mengacu pada teori comfort yang berdasarkan kebutuhan rasa nyaman pasien. Ketiga intervensi tersebut yaitu intervensi standart comfort yang diberikan untuk mengatasi kebutuhan rasa nyaman fisik, coaching untuk memenuhi kebutuhan rasa nyaman sosiokultural dan intervensi yang berhubungan dengan kenyamanan jiwa comfort food for soul untuk memenuhi kebutuhan rasa nyaman psikospiritual dan lingkungan.

Intervensi keperawatan untuk memberikan kenyamanan standar pada kelima pasien anak yang mengalami peningkatan suhu tubuh adalah mengkaji faktor penyebab demam, monitor suhu dan tanda-tanda vital, memonitor intake dan output, memonitor hidrasi (turgor, kelembaban, membran mukosa), memberikan cairan intravena, berkolaborasi pemberian antibiotik dan meningkatkan sirkulasi udara. Sedangkan intervensi coaching dan comfort food for soul dengan menganjurkan orangtua untuk menggunakan baju tipis pada anak dan terbuat dari kain katun, memberikan antipiretik dan mengajarkan kompres hangat pada lipat paha dan aksila jikasuhu diatas $37,5^{\circ} \mathrm{C}$ atau tepid sponge jikasuhu diatas $39^{\circ} \mathrm{C}{ }^{11}$.

Evaluasi untuk masalah peningkatan suhu tubuh pada kelima pasien setelah dilakukan asuhan keperawatan didapatkan hasil masalah teratasi. Suhu tubuh pasien setelah dilakukan asuhan keperawatanberada pada rentang suhu normal $36-37,5^{\circ} \mathrm{C}$. Evaluasi untuk kenyamanan anak yang dilakukan monitor pengukuran suhu tubuh menggunakan termometer temporal dari kelima pasien yang mengalami masalah utama peningkatan suhu tubuh dilakukan dengan menggunakan instrumen evaluasi yang berbeda yang disesuaikan dengan umur pasien. Tiga pasien diukur menggunakan behaviour checklist dan dua pasien menggunakan skala numerik ${ }^{12}$. Masalah kekurangan volume cairan juga teratasi dengan melihat perbaikan pada kondisi tugor kulit menjadi elastis, membran mukosa lembab. Masalah nutrisi dan bersihan jalan nafas juga 


\section{Wacana Kesehatan Vol. 4 , No.2, Desember 2019}

sudah menunjukkan perbaikan pada akhir waktu pemberian asuhan keperawatan walaupun ada beberapa pasien belum diperbolehkan pulang. Pasien by MRA sudah menurun demamnya tetapi anak mengalami sesak nafas sehingga masih harus dirawat dan meneruskan pengobatan ARV. Anak ARAG sudah turun demamnya tetapi mengalami ruam kemerahan dan didiagnosa morbili sehingga harus menjalani perawatan di ruang isolasi untuk perawatan lanjut.

\section{DISKUSI}

Pengkajian keperawatan yang dilakukan terhadap lima kasus menggunakan pendekatan teori kenyamanan Kolcaba dengan memperhatikan aspek kenyamanan fisik, psikospiritual, sosiokultural dan lingkungan. Hasil pengkajian berdasarkan keempat konteks kenyamanan selanjutnya dimasukan ke dalam struktur taksonomi kenyamanan untuk memudahkan perawat dalam melakukan intervensi.

Hasil pengkajian pada aspek kenyamanan fisik pada kelima pasien terpilih menunjukkan kelima pasien mengalami ketidaknyamaan fisik akibat peningkatan suhu tubuh. Masalah peningkatan suhu tubuh yang dialami anak tersebut membutuhkan tiga intervensi kenyamanan untuk menurunkan suhu tubuh sehingga anak memperoleh kenyamanan fisik. Ketiga intervensi itu adalah intervensi teknik mengukur kenyamanan (technical comfort measures), pembinaan (coaching), "Kenyamanan Food for the soul". Temuan lain pada pengkajian kenyamanan fisik didapatkan tiga anak mengalami batuk, dua anak mempunyai riwayat masuk rumah sakit karena kejang, satu anak mengalami diare dan tiga anak mengalami gangguan pertumbuhan dan perkembangan.

Pengkajian kenyamanan psikospiritual secara mendalam hanya dapat dilakukan pada dua pasien yaitu An MH (7,6 tahun) dan An. R.S (6,8 tahun) yang bisa dilakukan wawancara dan kooperatif karena telah berusia diatas 3 tahun sedangkan pada tiga pasien yang berusia kurang dari 3 tahun residen tidak melakukan wawancara lebih mendalam.

Pengkajian kenyamanan pada aspek sosiokultural mencakup perkembangan sosial anak baik interpersonal maupun intra personal. Hubungan anak dengan keluarga dan orang terdekat sebagai lingkungan sosial klien banyak dikaji pada aspek ini. Ketidaknyamanan sosial akan muncul jika pemberi pelayanan mengalami masalah dalam hubungan dengan anak. Hasil pengkajian sosiokultural pada kelima kasus didapatkan orang tua terutama ibu klien mengalami kecemasan karena kurang informasi penyakit dan perawatan anaknya.

Pengkajian kenyamanan lingkungan dengan melihat adaptasi anak dan keluarga terhadap lingkungan fisik di rumah sakit. Kondisi lingkungan yang dapat menimbulkan masalah kenyamanan bagi anak dan keluarga antara lain cahaya lampu ruangan, kebisingan, suhu ruangan yang terlalu panas/dingin, pengaturan ruangan. Lingkungan yang berbeda dapat menjadi stresor bagi anak dan keluarga. Anak dan keluarga yang tidak dapat beradaptasi dengan perbedaan lingkungan akan mengalami ketidaknyamaan lingkungan fisik ${ }^{7,12}$. Hasil pengkajian lingkungan keluarga tidak 


\section{Wacana Kesehatan Vol. 4 , No.2, Desember 2019}

mengalami gangguan pada kenyamanan lingkungan rumah sakit.

Pengkajian kenyamanan fisik, psikospiritual, sosiokultural dan lingkungan dapat dilakukan dengan baik dan tidak memerlukan waktu yang lama. Hasil pengkajian residen peroleh secara verbal atau dari klinis pasien dan menggunakan kuesioner kenyamanan yang dikembangkan Kolcaba. Komponen pengkajian pada format pengkajian comfort Kolcaba mempunyai komponen yang jelas sehingga mudah diaplikasikan $^{12}$. Tetapi meskipun aplikasi pengkajian konteks kenyamanan Kolcaba bisa diterapkan untuk semua usia tetapi dalam pelaksanaannya tetap ada kendala dalam penerapannya. Hal ini karena pengaruhi juga oleh ketrampilan perawat menemukan kebutuhan kenyamanan terutama pada pasien yang lebih muda usianya dan belum bisa melakukan komunikasi secara efektif sehingga hal itu berpengaruh pada penegakkan gangguan kenyamanan yang dialami ${ }^{13}$.

Diagnosa keperawatan utama pada kelima kasus adalah peningkatan suhu tubuh. Masalah ini dialami oleh kelima pasien yang mengalami penyakit infeksi dimana gelaja yang muncul pada pasien yang dengan penyakit infeksi baik disertai tanda lokal atau tidak ada tanda lokal gejala utamanya adalah demam ${ }^{2}$.

Masalah keperawatan kedua yang muncul adalah (risiko) kekurangan volume cairan. Masalah ini dialami oleh semua pasien penyakit infeksi karena salah satu tanda penyakit infeksi anak bisa mengalami asupan yang sulit ${ }^{2}$. Penurunan turgor kulit dan membran mukosa yang kering pada pengkajian sirkulasi dan hidrasi dapat menjadi penanda suatu penyakit serius ${ }^{14}$. Dehidrasi dapat terjadi pada anak dengan penyakit infeksi yang terjadi akibat penguapan kulit dan paru dan disertai ketidakseimbangan elektrolit yang mendorong suhu semakin tinggi ${ }^{4}$.

Diagnosa nutrisi kurang dari kebutuhan merupakan diagnosa yang mungkin muncul pada pasien anak yang mengalami penyakit infeksi. Demam yang tinggi yang dialami anak akan memacu metabolisme yang sangat cepat ${ }^{4}$. Kenaikan suhu yang dialami anak yang terinfeksi akan mempercepat aliran darah yang dapat mempercepat aliran makanan dan oksigenasi. Hal ini yang memugkinkan anak akan mengalami masalah nutrisi kurang dari kebutuhan.

Diagnosa keperawatan bersihan jalan nafas tidak efektif juga dapat ditemukan pada anak yang mengalami penyakit infeksi. Masalah ini muncul karena demam yang dialami anak dapat memacu metabolisme yang dapat menyebabkan peningkatan frekuensi nafas ${ }^{4}$. Pasien yang ditemukan masalah pada pengkajian pernafasan menunjukkan berisiko sedang sampai berat mengalami penyakit infeksi serius ${ }^{14}$.

Pengalaman psikospiritual pada kelima kasus kelolaan hanya dua anak yang dapat mengungkapkan secara verbal yaitu pada anak MH dan R.S yang dapat mengungkapkan rasa tidak nyaman. Sedangkan untuk ketiga anak yang lain dapat diketahui dari orang tua dimana orang tua menyatakan kekawatiran terhadap kondisi kesehatan anak.

Diagnosa keperawatan yang ditemukan pada ketidaknyamanan aspek sosiokultural adalah ansietas. Masalah ini dialami oleh kelima orang tua pasien kelolaan. Orang tua pasien yang 


\section{Wacana Kesehatan Vol. 4 , No.2, Desember 2019}

merupakan pemberi perawatan utama pada anak mengalami kecemasan terhadap perawatan anaknya. Dukungan yang diberikan tenaga kesehatan selama perawatan melalui pendidikan kesehatan tentang pengobatan dan perawatan anak dapat meningkatkan pemahaman orang tua sehingga akan memberikan kenyamanan orang tua.

Penegakkan diagnosa menggunakan pendekatan Kolcaba juga dapat residen lakukan tanpa kendala berarti. Diagnosa keperawatan residen tegakkan berdasarkan data dari pengkajian kenyamanan dan mengacu pada diagnosa keerawatan kenyamanan yang ada di NANDA.

Intervensi keperawatan untuk memberikan kenyamanan standar pada pasien yang mengalami peningkatan suhu tubuh adalah mengkaji faktor penyebab demam, monitor suhu dan tanda-tanda vital, memonitor intake dan output, memonitor hidrasi (turgor, kelembaban, membran mukosa), memberikan cairan intravena, berkolaborasi pemberian antibiotik dan meningkatkan sirkulasi udara. Sedangkan intervensi coaching dan comfort food for soul dengan menganjurkan orangtua untuk menggunakan baju tipis pada anak dan terbuat dari kain katun, memberikan anti piretik dan mengajarkan kompres hangat pada lipat paha dan aksila jikasuhu diatas $37,5^{\circ} \mathrm{C}$ atau tepid sponge jikasuhu diatas $39^{\circ} \mathrm{C}^{11}$.

Implementasi pengukuran suhu tubuh yang penulis lakukan adalah melakukan pengukuran suhu menggunakan termometer arteri temporal berdasarkan evidence based practice. Hasil implementasi didapatkan bahwa pengukuran suhu menggunakan termometer arteri temporal cukup menggambarkan peningkatan suhu tubuh anak walaupun nilainya tidak sebesar hasil pengukuran aksila dan timpani. Pengukuran suhu menggunakan termometer temporal juga lebih dapat mengurangi kecemasan dan ketakutan pada anak yang dihospitalisasi. Selama dilakukan pengukuran mengunakan ketiga jenis termomteter, hanya termomter temporal yang bisa lebih dirasa nyaman oleh anak yang dibuktikan anak tidak menangis, rewel dan terlihat ketakutan saat pengukuran suhu. Hal ini sesuai dengan prinsip asuhan atraumatik yang menekankan bahwa intervensi yang diberikan pada anak yang dirawat harus dapat meminimalkan dan mencegah stres fisik dan psikologis ${ }^{9,15}$.

Hasil penelitian tersebut sesuai dengan teknik pengukuran suhu tubuh yang direkomendasikan oleh Canadian task force on preventif healthstrenght of recommendationsmenyebutkan bahwa pengukuran suhu tubuh pada anak diatas usia 2 tahun dapat dipilih antara termometer aksila, timpani maupun temporal. Ketiga alat tersebut dapat mendeteksi peningkatan suhu tubuh anak dengan akurat. Keakuratan pengukuran suhu tubuh akan mempengaruhi petugas kesehatan dalam manajemen demam yang tepat ${ }^{16}$.

Evaluasi untuk masalah peningkatan suhu tubuh pada kelima pasien dapat teratasi, suhu tubuh klien setelah dilakukan perawatan suhu tubuh berada pada rentang suhu normal $36-37,5^{\circ} \mathrm{C}$. Masalah kekurangan volume cairan juga teratasi dengan melihat perbaikan pada kondisi turgor kulit menjadi elastis, membran mukosa lembab. Masalah nutrisi dan bersihan jalan nafas juga sudah menunjukkan perbaikan pada akhir waktu pemberian asuhan keperawatan walaupun ada 
Wacana Kesehatan Vol. 4 , No.2, Desember 2019

beberapa pasien belum diperbolehkan pulang. Pasien by MRA sudah menurun demamnya tetapi anak mengalami sesak nafas sehingga masih harus dirawat dan meneruskan pengobatan ARV. Anak ARAG sudah turun demamnya tetapi mengalami ruam kemerahan dan didiagnosa morbili sehingga harus menjalani perawatan di ruang isolasi untuk perawatan lanjut.

Evaluasi kenyamanan pengukuran suhu menggunakan ketiga alat pengukur suhu tubuh yaitu thermometer arteri timpani, termometer aksila dan termometer timpani pada kelima pasien yang mengalami masalah utama peningkatan suhu tubuh dilakukan dengan menggunakan instrumen evaluasi yang berbeda disesuaikan dengan umur pasien ${ }^{12}$. Klien bayi MRA dan MRAF walaupun kesadaran komposmentis tetapi karena usia masih dibawah satu tahun sehingga penulis melakukan pengukuran kenyamanan dengan kenyamanan behaviour checklist. Pasien ARAG sudah berusia diatas satu tahun tetapi karena klien mengalami keterlambatan bicara tidak memungkinkan dievaluasi tingkat kenyamanan dengan skala bunga daisi, pertanyaan tertutup maupun VAS, sehingga penulis juga mengukur kenyamanan klien dengan behaviour checklist. Sedang untuk anak MH dan MRS yang telah berusia diatas 5 tahun tidak ditemui kesulitan dalam melakukan pengukuran kenyamanan menggunakan skala numerik. Evaluasi kenyamanan dilakukan pada semua pasien setelah pasien dilakukan tindakan monitor suhu tubuh menggunakan ketiga alat pengukur suhu tubuh. Kelima pasien ketika diberikan instrumen untuk menilai tingkat kenyamanan terhadap pengukuran suhu tubuh yang diberikan menunjukkan nilai kenyamanan pada skala yang sedang dan tinggi ${ }^{13}$.

\section{Simpulan}

Hasil pengukuran suhu tubuh berdasarkan evidence based practice menggunakan tiga termometer dapat diterapkan pada pasien yang mengalami masalah peningkatan suhu tubuh di ruang infeksi. Hasil pengukuran suhu menggunakan termometer temporal dapat menggambarkan peningkatan suhu tubuh inti pada anak dan anak merasa lebih nyaman dimana hal ini sesuai dengan prinsip asuhan atraumatik yang harus diterapkan pada anak.

Aplikasi teori kenyamanan Kolcaba dapat digunakan pada asuhan keperawatan anak dengan penyakit infeksi yang mengalami peningkatan suhu tubuh. Pemberian asuhan keperawatan dengan pendekatan teori comfort Kolcaba pada kelima kasus keloaan anak dapat diterapkan mulai dari tahap pengkajian, perumusan diagnosa keperawatan, intervensi, implementasi dan evaluasi karena memiliki komponen pengkajian, intervensi dan evaluasi yang jelas.

Kasus-kasus kelolaan yang diberikan asuhan keperawatan dengan pendekatan teori kenyamanan Kolcaba semua mengalami masalah utama peningkatan suhu tubuh disertai masalah masalah keperawatan yang lain seperti bersihan jalan nafas tidak efektif, kekurangan volume cairan, nutrisi kurang dari kebutuhan, gangguan keterlambatan pertumbuhan dan perkembangan anak, risiko kejang berulang, risiko komplikasi, gangguan pola eliminasi (bab cair) dan perubahan proses keluarga. 


\section{Wacana Kesehatan Vol. 4 , No.2, Desember 2019}

Lama pemberian asuhan keperawatan yang diberikan terhadap kelima pasien terpilih ratarata adalah lima hari perawatan. Gambaran akhir kelima kasus yang telah diberikan asuhan keperawatan bahwa belum semua pasien dapat menemukan tiga tipe kenyamanan Kolcaba. Bayi MRA dan anak ARAG yang pada akhir perawatan sudah tidak demam tetapi masih mengalami masalah pernafasan dan gangguan kulit sehingga kenyamanan relief, ease dan transendence belum tercapai. Sedangkan untuk pasien GPA, MRS, ARAG pada hari kelima pemberian asuhan keperawatan sudah stabil suhu tubuhnya dan masalah keperawatan lain telah teratasi sehingga diijinkan pulang telah mencapai kenyamanan relief, ease dan transendence. Hasil evaluasi kelima pasien didapatkan tiga pasien diijinkan pulang oleh dokter pada hari kelima pemberian asuhan keperawatan, sedangkan dua pasien masih harus menjalani perawatan lebih lanjut karena masih mengalami masalah pada kenyamanan fisik (inefektif pola nafas dan gangguan integritas kulit).

Evaluasi kenyamanan kelima pasien yang mengalami masalah utama peningkatan suhu tubuh dan dilakukan monitor suhu tubuh menggunakan ketiga jenis termometer dilakukan dengan menggunakan instrumen evaluasi yang berbeda disesuaikan dengan umur pasien ${ }^{12}$. Tiga pasien dilakukan pengukuran kenyamanan dengan kenyamanan behaviour checklist dan dua anak dilakukan pengukuran kenyamanan menggunakan skala numerik dengan nilai kenyamanan pada skala yang sedang dan tinggi ${ }^{13}$. Pengukuran suhu menggunakan termometer arteri temporal didapatkan hasil mampu menggambarkan peningkatan suhu tubuh inti pada anak dan anak yang diukur merasa lebih nyaman. Dengan demikian diharapkan perawat melakukan manajemen demam yang tepat diantaranya melalui monitor suhu tubuh menggunakan thermometer arteri temporal.

\section{Ucapan terimakasih}

Terimakasih kami sampaikan pada Yayasan Dharma Wacana Metro, Direktur RSUPN Cipto Mangunkusumo, RSAB Anak Bunda Harapan Kita, RSPAD Gatot Subroto Jakarta, dan orang tua pasien anak infeksi yang mengalami demam.

\section{Referensi}

1. Ismoedijanto, 2004. Metode Diagnostik Typoid pada Anak. Bagian SMF Ilmu Kesehatan Anak FK UNAIR RSUD Dr. Soetomo, Surabaya

2. Marcdante, K.J., Kliegman, R.M., Jenson, H.B., \& Behrman, R.E. (2011). Nelson essensial of pediatrics (6th ed). Singapore: Elsevier.

3. Potter, P.A. \& Perry, A.G. (2009). Fundamentals of nursing 7th edition. Singapore : Elsevier.

4. Sherwood, L. (2013). Introducing to human physiology, 8th edition. Brooks. Cengage learning.

5. Batra, P. \& Goyal, S. (2013). Comparison of Rectal,Aaxillary, Tympanic, and 
Wacana Kesehatan Vol. 4 , No.2, Desember 2019

Temporal Artery thermometry in the

pediatric emergency room.diunduh pada

tanggal 23 Februari 2016 dari

http://www.ncbi.nlm.nih.gov/pubmed/2328

$\underline{3266}$

6. Allegaert, K., Casteels, K., Gorp, I.V., \& Bogaert, G. (2014). Tympanic, infrared-

skin, and temporal artery scan

thermometers compared with rectal

measurement in children : a real-life

assesment. Current Therapeutic Research.

$76,34-38$.

7. Peterson, S.J. \& Bredow, T.S. (2013).

Middle range theories: application to nursing research. Walnut Street,

Philadelphia: Lippincott Williams \& Wilkins.

8. PPNI. (2005). Standar kompetensi perawat Indonesia. Jakarta: Inna PPNI.

9. Walsh, A.M., Edwards, H.E., Courtney, M., Wilson, J. \& Monangan, S. (2005).

Paediatric nurses knowledge attitude and factors influencing fever management.

Juornal of Advandced Nursing. 49 (5), 453464.

10. Walsh, A.M., Edwards, H.E. \& Fraser, J.A. (2008). Parents childhood fever management: Community survey and instrument development. Juornal of Advandced Nursing. 63 (4), 376-388.
11. Tomey, A.M., \& Alligood, M.R. (2006). Nursing theory and their work. Missoury: Mosby.

12. Bulechek, G.M., Butcher, H.K., Dochterman, J.M., \& Wagner, C.M. (2013). Nursing interventions clasification (NIC). Six edition. St. Louis Missouri:

Elsevier.

13. Kolcaba, K., \& DiMarco, M. (2005). Comfort theory and its application to pediatric nursing. Pediatric Nursing, 31(3), 187-194. Retrieved from http://www.pediatricnursing.netpada tanggal 25 Oktober 2013

14. Alligood, M.R. (2014). Nursing theorists and their work. Eigth edition. Mosby: Elsevier:

15. Bridgwater, K., Fletcher, M., Hatter, E.H. Houghton, J., Mason, C. \& Monaghan, J. (2015). Caring for children with fever. London : Royal College of Nursing.

16. El- Radhi, A.S. \& Barry, W. (2006). Thermometry in paediatric practice. Arch Dis Child; 91, 351-356.

17. Leduc, D. \& Woods, S. 2000. Temperature measurement in paediatrics. Canadian Paediatric Society. 